\title{
COOLING ENERGY AND PASSIVE ENERGY SAVING STRATEGIES FOR MASTER BEDROOM OF A TROPICAL BUNGALOW HOUSE
}

\author{
Saber Sabouri $^{1 *}$, Mohamad Fauzi Mohd Zain ${ }^{1}$ \\ ${ }^{1}$ Faculty of Engineering and Built Environment, Universiti Kebangsaan Malaysia, Bangi, Selangor,Malaysia \\ *sbrsabouri@gmail.com
}

\begin{abstract}
Bungalow as a low density house is one of the three major house types in Malaysia. In tropical countries, cooling of spaces has a main portion of energy consumption of buildings. In Malaysian houses, bedrooms are cooled mostly and it occurs in nighttime. In this study, a bungalow house was simulated by DesignBuilder software and calibrated with its annual electrical bills. Then, effects of five passive strategies were explored separately. Results showed that applying appropriate window and proper insulation could save $72.6 \%$ and $36.4 \%$ cooling energy of master bedroom, respectively. Maximum saving of cooling energy due to best orientation was $12.3 \%$. Higher ratio of window to wall area for north wall was more suitable than west wall. But difference of their cooling energy was not so intensive. Existence of balcony with $1.6 \mathrm{~m}$ depth attached to external walls of master bedroom will save $31 \%$ chiller electricity compared to without balcony condition. Integration of these strategies in a bungalow house showed approximately no need for cooling energy of master bedroom with $28^{\circ} \mathrm{C}$ cooling set point. Also, it was $97.5 \%$ and $87 \%$ saving of cooling energy with $27^{\circ} \mathrm{C}$ and $26^{\circ} \mathrm{C}$ cooling set points of master bedroom, respectively.
\end{abstract}

Keywords: Simulation, Bungalow house, Cooling Energy, Passive Energy Saving, Chiller Electricity

\section{Introduction}

Residential sector has about $16-50 \%$ of total energy consumption in the world countries. Malaysia as a developing country has 19\% energy consumption in residential sector in comparison with all other sections (Saidur, Masjuki, \& Jamaluddin, 2007).This significant amount of consumption invokes a scrutiny in residential sector's energy consumption. For preventing energy consumption growth and even its decreasing, it seems necessary to have appropriate view in energy supply, efficient use, and effects of consumption. In residential sector, energy is consumed for achieving human comfort in three ways:

1. Space heating (SH), space cooling (SC)

2. Domestic hot water (DHW)

3. Appliances and lighting (AL) (Swan \& Ugursal, 2009).

In this study, passive strategies for reduction of energy consumption for space cooling are considered.

In Malaysia there are three main different types of low density house plans: terraced house, semi-detached house, and bungalow (detached) house. In this survey a typical Malaysian bungalow house is selected in suburb area of Kuala Lumpur and is simulated in DesignBuilder (DB) software. "DB" is a user friendly graphical interface for Energy Plus program; simulation program of energy department of US. In "DB" energy consumption of building is broken down to electricity of room equipment, lighting, DHW and chiller electricity (Tindale, 2002). In this bungalow house, DHW electricity consumption is supplied by photovoltaic sheets that installed in pitched roofs and 
DHW energy consumption is ignored. In this house, cooling is only available in master bedroom. So, its design could be improved for energy saving purposes. Here, some architecture strategies are selected and simulated for energy saving. These strategies could be considered by architects in first stages of house design. The proposed passive strategies are related to architectural details including:

1. Appropriate window

2. Wall and roof insulation

3. Orientation

4. Window to wall area ratio (WWR)

5. Balcony and its location.

These strategies are considered with respect to cooling set point temperature. These properties and their influence on energy consumption of bungalow house are explored separately. In next stage, an integrative design alternative is proposed. Finally, the percentage of energy saving is described in proposed house in comparison with primitive model as a BASECASE.

\subsection{Climatic Condition in Kuala Lumpur, Malaysia}

Malaysia is a tropical country with hot and humid climate. Kuala Lumpur, the capital city, is located in $3.12^{\circ}$ north latitude and $101.55^{\circ}$ east longitude. This geographical position causes hot and humid climate throughout full daytime. Figure 1 shows annual dry bulb temperature in Kuala Lumpur. Minimum and maximum dry bulb temperatures are $23.48^{\circ} \mathrm{C}$ and $32.30^{\circ} \mathrm{C}$, respectively. Temperature approximately all of year is between $24-38^{\circ} \mathrm{C}$.

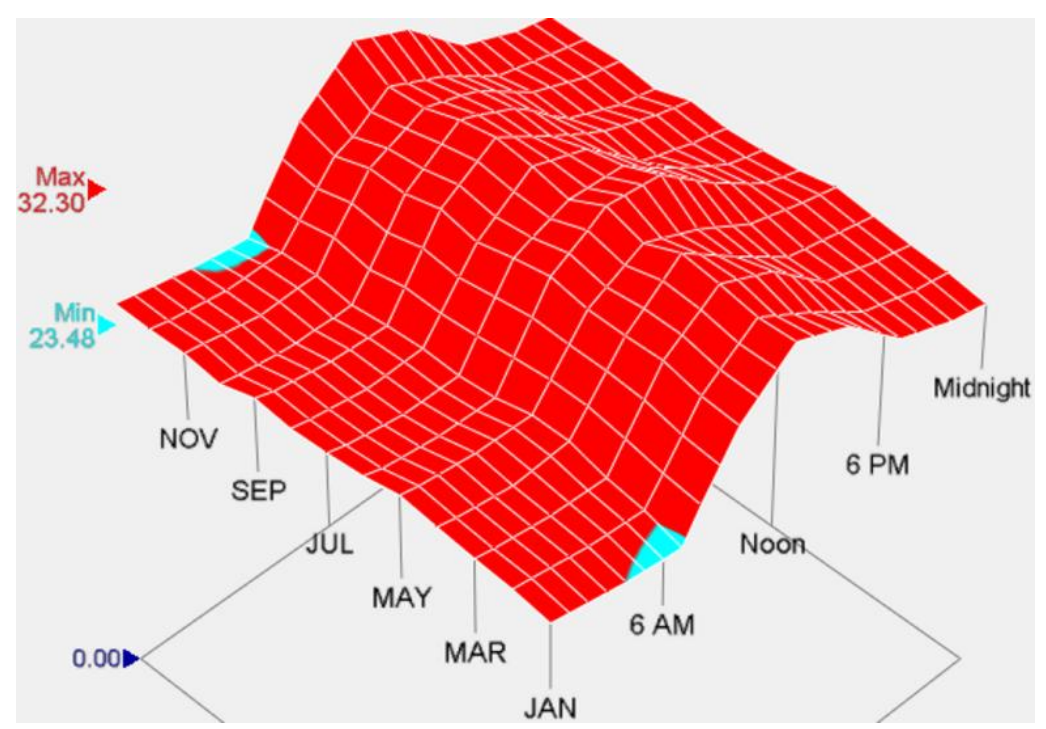

Figure 1: Annual dry bulb temperature in Kuala Lumpur (Ligget \& Milne, 2008) 
Kuala Lumpur is affected by Malaysian the south-west monsoon from April to September. However, there is not a lot of difference in rainfall in comparison with rest of year. The average humidity of Malaysia is $83 \%$ (Ahmad, 2008). The psychrometric chart of Kuala Lumpur shows that climatic condition is not inside thermal comfort area (Figure 2). So, buildings need HVAC system to achieve thermal comfort. However, some passive cooling techniques could reduce energy demands. In addition, residential function has suitable flexibility to adaptive behaviors. Also, ethnic factor could be considered for enlarging comfort conditions.

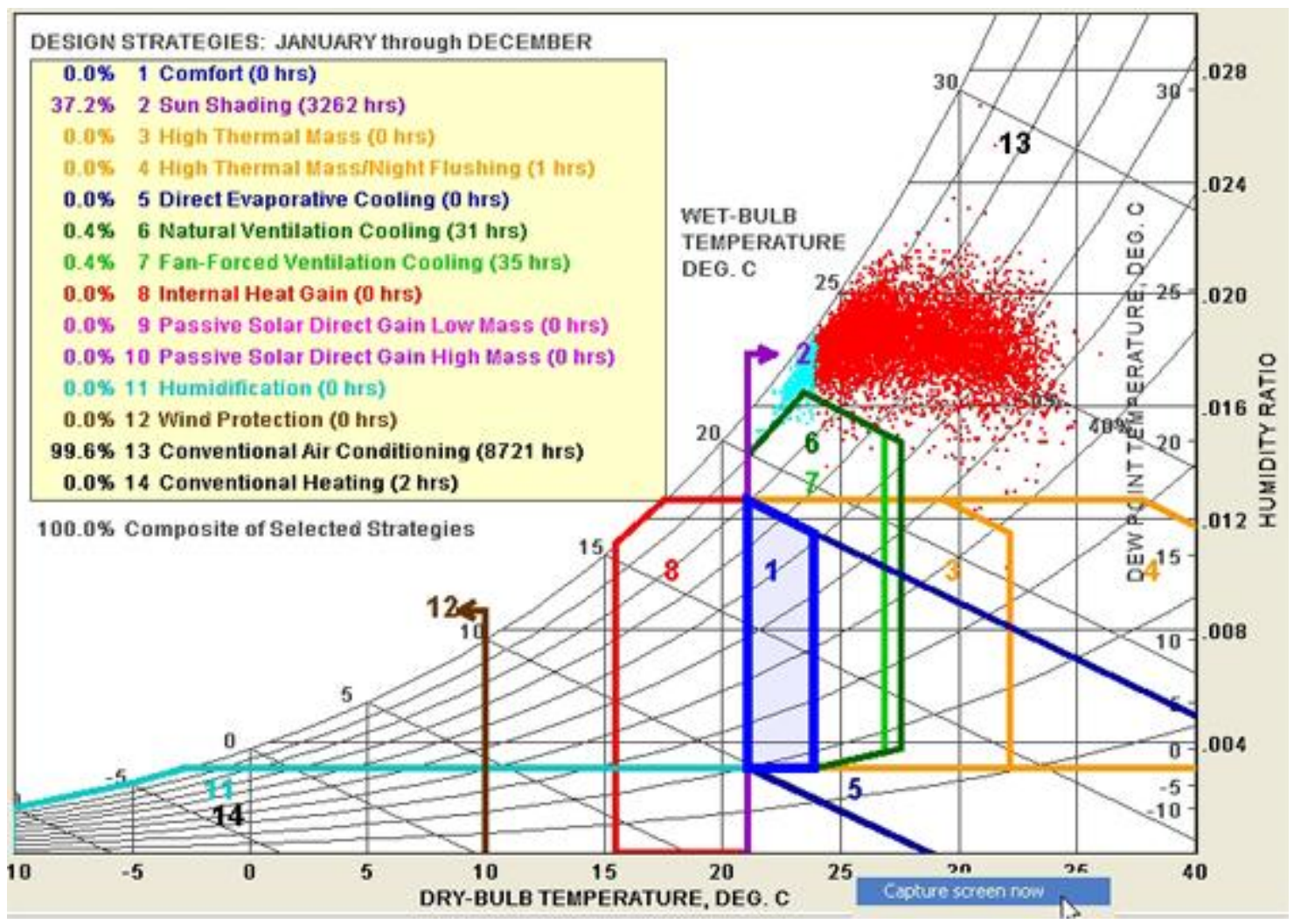

Figure 2: Kuala Lumpur in outside of comfort zone of psychrometric chart (Ligget \& Milne, 2008)

\subsection{Previous Researches}

There is only limited number of research literature on energy-efficient house design in hot and humid climates. Some previous studies have been done for energy efficiency in different countries. But there are not enough studies in Malaysia. Bungalow house is one of main house types in Malaysia and it is essential to have appropriate view for energy efficient design. Energy regulations have been explored in the Gulf States for a residential building. A Bahraini single storey house has been simulated by "DB" and its components effect on internal thermal comfort has been examined. In this case study simulation was in accordance with characteristics of house and it was calibrated by monthly utility bills (Radhi, Eltrapolsi, \& Sharples, 2009). Other research has been done in an institutional building in sub-tropical climate in Australia. Energy conservation measures (ECMs) were 
surveyed as three main categories: major, minor and zero investment ECMs. "DB" has been applied as simulation software in this study. Building was divided to thermal zones by "DB" and its simulation was based on "Energy Plus" program. Three parameters were applied for its calibration including: average hourly internal temperature, average hourly relative humidity and average hourly total energy consumption of summer and winter day (Rahman, Rasul, \& Khan, 2010). Perez and Capeluto (2009) presented guidelines for school design for promoting energy efficiency in hot and humid region. They found that various design factors could have influence in each other and energy consumption. However, it could be achieved appropriate energy savings. For example, reducing artificial lighting could reduce energy consumption. They used "ENERGY" hourly dynamic simulation software for exploring energy and lighting performance of building. Validation of results was by comparing by analytical cases and measurements in a full-scale building (Perez \& Capeluto, 2009). Another study has been done about residential envelope design in hot summer and cold winter zone in China. A residential building was simulated with eQuest (based on DOE-2) software and appropriate design choices led to significant energy saving. They studied energy performance effect of insulation, solar absorptance, and window to wall area of exterior walls, shading and double glazing for windows. Refurbished building got $25.92 \%$ energy saving for mentioned strategies (Yu, Yang, \& Tian, 2008). Cheung et al. (2005) applied passive cooling design strategies in high rise apartments in Hong Kong and achieved 31.4\% energy saving in annual cooling requirements. TRNSYS software was chosen for simulation. They have chosen five passive cooling strategies including: insulation and thermal mass, color of external walls, glazing systems, window area and shading (Cheung, Fuller, \& Luther, 2005). Garde et al. (2004) have examined passive cooling strategies (such as solar protection, natural ventilation) in French tropical residential buildings. They have proposed some regulations for architects. They have also made experimental and sociological surveys on effects of these passive strategies (Garde, Adelard, Boyer, \& Rat, 2004). Saidur (2009) explored energy consumption and saving in Malaysian offices. It was understood that most part of energy was consumed in air conditioning. Energy saving could be obtained by application of advance glazing, compact fluorescent lamps (CFL), insulation, housekeeping, raising thermostat set point temperature of air conditioners and reducing EI(energy intensity) (Saidur, 2009). These studies emphasize on importance of architecture design in energy savings. In this study, bungalow house is concentrated with its architectural properties and life style of people who live in it.

\subsection{The simulation with DesignBuilder}

There are some energy simulation programs and tools such as DOE2, Energy-10, and Energy Plus. In this study, Energy Plus is used for simulation. Energy Plus as a simulation program models heating, cooling, lighting, ventilating and other energy flows. It has many capabilities to simulate various time steps and plant integrated with heat balance-based zone simulation, thermal comfort and energy used and so on (http://apps1.eere.energy.gov/buildings/energyplus/). It is a state-of-the-art software tool for checking building energy, carbon, lighting and thermal demands (Tindale, 2002). In this section, firstly the bungalow house properties as a BASECASE model are described. Then some inputs for simulation in "DB" are indicated. Finally the BASECASE is verified. 


\subsection{The BASECASE Model}

As it described, bungalow house is one of the most common low density buildings in Malaysia. In this research a two storey bungalow house was selected in Bangi, Selangore region near Kuala Lumpur. Main spaces of this house are living room, guest room, and kitchen in ground floor, master bedroom with three bedrooms and their bathes in first floor (Figure 3). Ground floor and first floor areas are $122.5 \mathrm{~m}^{2}$ and $120.5 \mathrm{~m}^{2}$, respectively. Total area of the building is $243 \mathrm{~m}^{2}$. The building constructed with reinforced concrete structure and has pitched roofs that covered with concrete tiles. There are no insulation in walls and roofs. Building orientation is east-west and has aluminum framed windows with single clear glazing. Architectural characteristics of building are presented in Table 1.

Table 1: Description of bungalow house (low density house)

\begin{tabular}{|ll|}
\hline Parameters & Value \\
Number of floors & 2 \\
Ground floor area & $122.5 \mathrm{~m}^{2}$ \\
First floor area & $120.5 \mathrm{~m}^{2}$ \\
Total area & $243 \mathrm{~m}^{2}$ \\
Orientation & East-west \\
Balcony & One balcony with $1.6 \mathrm{~m}$ depth and $5.1 \mathrm{~m}$ length at west side, concrete \\
& $($ medium density $)$ \\
External walls & Cement sand render $(1.3 \mathrm{~cm})+$ concrete block $(11 \mathrm{~cm})+$ gypsum \\
Internal walls & plastering $(1.3 \mathrm{~cm})$ \\
Pitched roof & Concrete block $(11 \mathrm{~cm})+$ inner/outer gypsum plastering $(1.3 \mathrm{~cm})$ \\
Ceiling & Wooden batons $(20 \mathrm{~cm})+$ air gap $(10 \mathrm{~cm})+$ concrete tiles $(2 \mathrm{~cm})$ \\
Flat roof & Tiles $(10 \mathrm{~mm})$ \\
Window & Asphalt $(1.9 \mathrm{~cm})+$ fiberboard $(1.3 \mathrm{~cm})+$ concrete reinforced $(10 \mathrm{~cm})$ \\
Infiltration rate & Aluminum framed window, single glazing $(6 \mathrm{~mm})$ \\
Lighting & 0.5 ac/h \\
Occupancy & Fluorescent, compact $\left(4.6 \mathrm{w} / \mathrm{m}^{2}-100\right.$ lux $)$ \\
\hline
\end{tabular}

Only space with cooling equipment is master bedroom. The cooling system is split with no fresh air. There is not any mechanical air conditioning in rooms of building. Area of master bedroom is $24.7 \mathrm{~m}^{2}$ and its height is $3.8 \mathrm{~m}$ and has a pitched roof with $25^{\circ}$ slope. Its climax height is $5.76 \mathrm{~m}$. It has two external walls oriented to northward and westward. Length of northward wall is $4.1 \mathrm{~m}$ and its window to wall area ratio (WWR) is $10.6 \%$. North wall has two windows with $0.6 \mathrm{~m}$ length and $1.75 \mathrm{~m}$ height. For westward wall, length of wall and WWR are 
$4.6 \mathrm{~m}$ and $43 \%$, respectively. It has three large windows with $1.2 \mathrm{~m}$ length and $2.1 \mathrm{~m}$ height. Building windows have no shading and there is one balcony with $1.6 \mathrm{~m}$ depth attached to westward wall. Cooling set point of air temperature for master bedroom is $28^{\circ} \mathrm{C}$. Figure 3 and 4 illustrate architecture plans and image of simulated house, respectively.
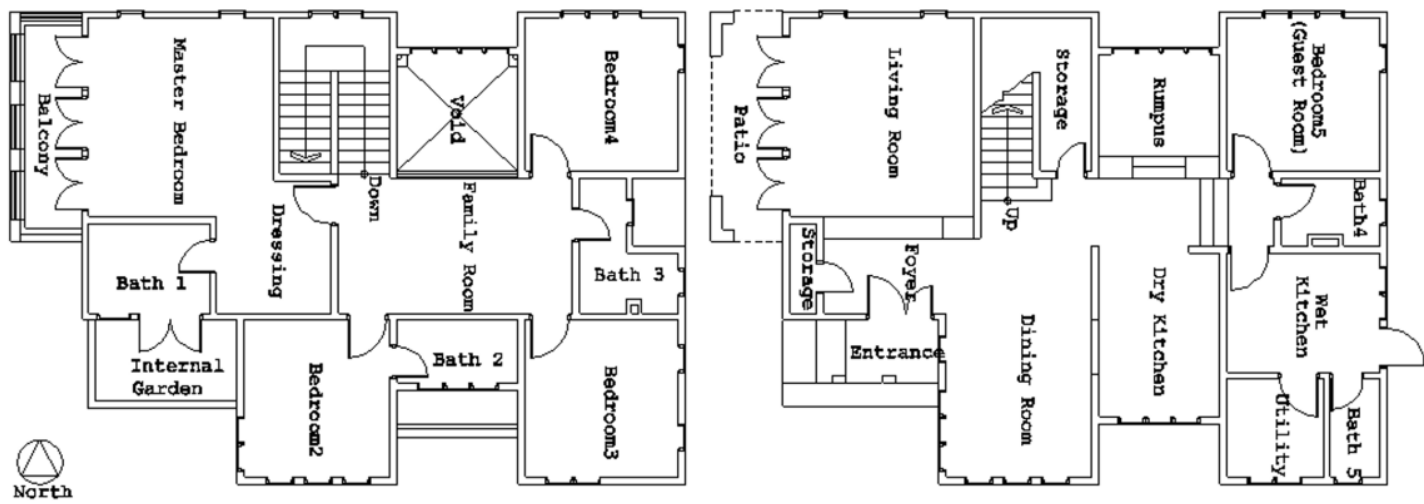

Figure 3: Architecture plans of bungalow house, left: first floor, right: ground floor

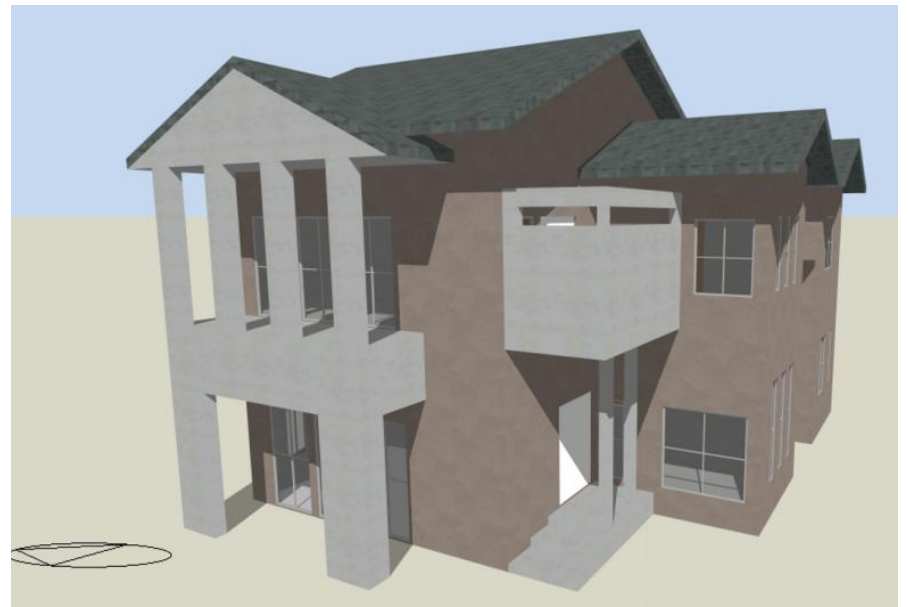

Figure 4: Image of bungalow house simulated by "DB"

\subsection{Inputs for Simulation}

For simulation in "DB", five categories of data would be implemented including: activity, construction, opening, lighting and HVAC system. Building physical properties were added in accordance with Table1. Occupation and HVAC operation schedule were entered with considering HVAC system and operation schedule of BASECASE house. It was in congruence with previous researches in Malaysia. According to Kubota et al. (2009), the most of air conditions of Johor Bahru houses, second largest city in Malaysia, have been installed mainly in their bedrooms; master bedroom (94\%), other bedrooms (52\%), living room (29\%) and dining room (5\%). Their research 
also indicates that most of the owners operate them at night and use air-conditioners for sleeping (Kubota, Chyee, \& Ahmad, 2009). In BASECASE model, split system is only in master bedroom and it works at nighttime. There is also nighttime natural ventilation for master bedroom. Rest of spaces has no cooling system but these spaces use scheduled natural ventilation. Operation schedule of HVAC system of main space types could be seen in Table 2

Table 2: HVAC type and its operation schedule

\begin{tabular}{|c|c|c|}
\hline Abbreviation & Weekdays and holidays & Weekends \\
\hline Bedroom & 5p.m.-9a.m & $\begin{array}{l}\text { 5p.m. - 9a.m, 9a.m. }-5 \text { p.m. on } \\
\text { setback temperature }=30^{\circ} \mathrm{C}\end{array}$ \\
\hline Living room and kitchen & 5a.m.-9a.m., 5p.m.-12a.m. & 5a.m.-12a.m. \\
\hline
\end{tabular}

\subsection{Verification of BASECASE}

The weather data of simulation was weather report of Kuala Lumpur, Subang weather station in 2002. This file is available at Energy Plus website. As mentioned, energy consumption of the house is related to space cooling, domestic hot water (DHW), electrical consumers (lighting and appliances) and life style of occupants. Monthly amounts of electricity consumption were retrieved from simulation results of bungalow house by "DB". Simulation was calibrated with respect to monthly electrical bills of bungalow house,. Monthly results of simulation are presented in Table 3

Table 3: Monthly results of electricity consumption in bungalow house retrieved from simulation

\begin{tabular}{|l|l|l|l|l|l|l|l|l|l|l|l|l|}
\hline & $1 / 1$ & $1 / 2$ & $1 / 3$ & $1 / 4$ & $1 / 5$ & $1 / 6$ & $1 / 7$ & $1 / 8$ & $1 / 9$ & $1 / 10$ & $1 / 11$ & $1 / 12$ \\
\hline Electricity $(\mathrm{kWh})$ & 627 & 580 & 693 & 637 & 647 & 726 & 672 & 656 & 626 & 601 & 608 & 598 \\
\hline
\end{tabular}

Because of approximately permanent weather condition of Malaysia, average of electrical bills of house was applied. Average of monthly electrical bills was around $645(\mathrm{kWh})$ and average of simulation was $639.8(\mathrm{kWh})$ that could be acceptable resolution.

In tropical climate, cooling and dehumidification of spaces are important for indoor thermal comfort. Solar protection and natural ventilation could be passive strategies for these works. Here, strategies were considered for bungalow house that could decline solar heat gains. Window and its properties, insulation for walls and roofs, orientation, area of window to wall existence of balcony and its influence were explored separately. 


\subsection{Results and Discussion}

\subsection{Tested Parameters}

As mentioned, five architectural design factors and their impact on cooling energy demand were tested. In this section the results are presented and discussed.

\subsubsection{Appropriate Window}

U-values of different parts of a building envelope show that the weakest point in a building is the window. According to Szokolay, U-value of a window is related to glazing, frame, frame thickness and exposure (Szokolay, 2008). Glazing could be included single glazing and double glazing windows with different glass types such as low emissivity, reflective, clear or colored glasses. Frames could be aluminum, painted wooden and UPVC window frames. Windows exposure could be changed with window blinds and local shadings. Local shading includes louvers, overhangs and side fins. BASECASE model windows are aluminum framed with single clear glazing and $6 \mathrm{~mm}$ thickness. Glazing as a more effective component of window was focused and emission and reflection properties as main solar features of it were studied.

Tested windows in this study consist of reflective and low emissivity double glazing windows with aluminum frame. Overhang, louvers and side fins are used as exposure control elements. Various tested window types have presented in Table 4.

Table 4: Window type

\begin{tabular}{|c|c|c|c|}
\hline Abbreviation & \multicolumn{2}{|c|}{ U-value $\left(\mathrm{W} / \mathrm{m}^{2} / \mathrm{K}\right) \mathrm{SHGC}$} & Specification from outside to inside \\
\hline Window 1 & 5.77 & 0.819 & $\begin{array}{l}\text { BASECASE model, single glazing clear, glass } 6 \mathrm{~mm} \text {, } \\
\text { aluminum frame }\end{array}$ \\
\hline Window 2 & 2.665 & 0.703 & $\begin{array}{l}\text { Double glazing clear, inner/outer pane } 6 \mathrm{~mm} \text {, window gap } \\
\text { type: air } 13 \mathrm{~mm} \text {, aluminum frame }\end{array}$ \\
\hline Window 3 & 1.493 & 0.568 & $\begin{array}{l}\text { Double glazing low emissivity, outer pane: low emissivity } \\
6 \mathrm{~mm} \text {,inner pane: clear } 6 \mathrm{~mm} \text {, window gap type: argon filled } \\
13 \mathrm{~mm} \text {, aluminum frame }\end{array}$ \\
\hline Window 4 & 2.761 & 0.154 & $\begin{array}{l}\text { Double glazing reflective, outer pane: reflective, } \\
\text { metallic(stainless steel) painted, low emissivity, } 6 \mathrm{~mm} \text {, inner } \\
\text { pane: clear } 6 \mathrm{~mm} \text {, window gap type: air } 6 \mathrm{~mm} \text {, aluminum frame }\end{array}$ \\
\hline Window 5 & 2.013 & 0.131 & $\begin{array}{l}\text { Double glazing reflective, outer pane: reflective, } \\
\text { metallic(stainless steel) painted, low emissivity, } 6 \mathrm{~mm} \text {, inner } \\
\text { pane: clear } 6 \mathrm{~mm} \text {,window gap type: argon filled } 13 \mathrm{~mm} \text {, } \\
\text { aluminum frame }\end{array}$ \\
\hline
\end{tabular}




\begin{tabular}{|c|c|c|c|}
\hline Window 6 & 1.493 & 0.568 & $\begin{array}{l}\text { Double glazing low emissivity with shading, outer pane: low } \\
\text { emissivity } 6 \mathrm{~mm} \text {, inner pane: clear } 6 \mathrm{~mm} \text {, window gap type: } \\
\text { argon filled } 13 \mathrm{~mm} \text {, aluminum frame, } 1 \mathrm{~m} \text { louver, } 1 \mathrm{~m} \text { overhang } \\
\text { and side fins }\end{array}$ \\
\hline Window 7 & 2.761 & 0.154 & $\begin{array}{l}\text { Double glazing reflective with shading, outer pane: reflective, } \\
\text { metallic (stainless steel) painted, low emissivity, } 6 \mathrm{~mm} \text {, inner } \\
\text { pane: clear } 6 \mathrm{~mm} \text {, window gap type: air } 6 \mathrm{~mm} \text {, aluminum frame, } \\
1 \mathrm{~m} \text { louver, } 1 \mathrm{~m} \text { overhang and side fins }\end{array}$ \\
\hline Window 8 & 2.013 & 0.131 & $\begin{array}{l}\text { Double glazing reflective, outer pane: reflective, metallic } \\
\text { (stainless steel) painted, low emissivity, } 6 \mathrm{~mm} \text {, inner pane: } \\
\text { clear } 6 \mathrm{~mm} \text {, window gap type: argon filled } 13 \mathrm{~mm} \text {, aluminum } \\
\text { frame, } 1 \mathrm{~m} \text { louver, } 1 \mathrm{~m} \text { overhang and side fins }\end{array}$ \\
\hline
\end{tabular}

Energy consumption of master bedroom with eight types of tested windows have displayed in Figure 5. It could be realized that window 2 (Double glazing clear, inner/outer pane $6 \mathrm{~mm}$, window gap type: air 13mm, aluminum frame) has $9.5 \%$ energy saving in comparison with BASECASE model. Low emissivity and existence of reflectivity in double glazing have significant decrease in energy use of master bedroom. Window 3(double glazed with low emissivity) and window 5 (double glazed with integrated low emissivity and reflectivity) have $22 \%$ and $62 \%$ energy saving, respectively. Comparison of window 4 and window 5 shows that changing air gap type form air $(6 \mathrm{~mm})$ to argon filled $(13 \mathrm{~mm})$ will decrease $2.5 \%$ energy consumption of BASECASE model. Overhang and louver will decrease sun light entrance to inside of building and consequently energy consumption. Window 6, 7 and 8 are same as window 3, 4 and 5, respectively. However, they also have $1 \mathrm{~m}$ louver, $1 \mathrm{~m}$ overhang and side fins as shading. So, window 6,7 and 8 have $25 \%, 6.8 \%$ and $9.9 \%$ more energy savings. This matter indicates that shading in low emissivity window is more observable than reflective windows. Also, it could be seen that window 8 has lowest energy consumption. Its energy consumption is $72.6 \%$ lower than BASECASE model. This issue shows importance of selecting appropriate window to approach energy efficient space. 


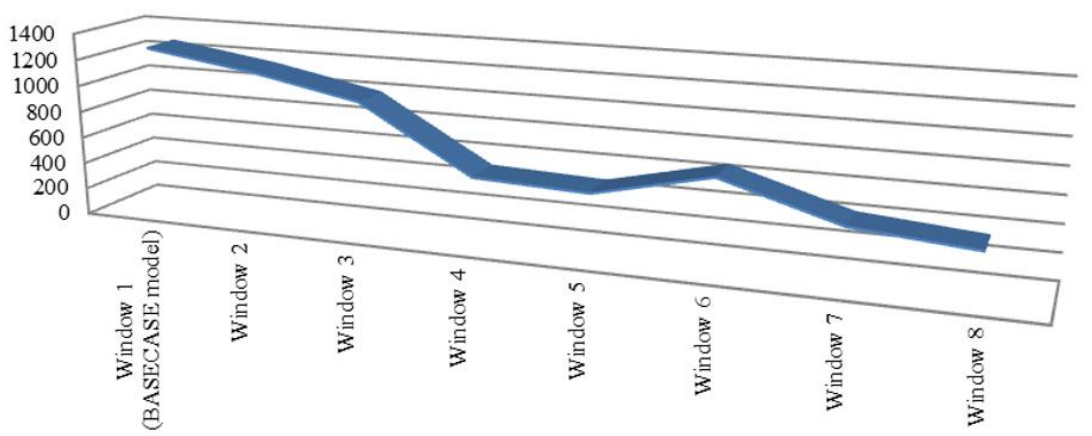

\begin{tabular}{|l|c|c|c|c|c|c|c|c|}
\cline { 2 - 2 } & $\begin{array}{l}\text { Window 1 } \\
\text { (BASECA } \\
\text { SE model) }\end{array}$ & Window 2 & Window 3 & Window 4 & Window 5 & Window 6 & Window 7 & Window 8 \\
\hline
\end{tabular}

Figure 5: Chiller Electricity (kWh) and different window types

\subsubsection{Wall and Roof Insulation}

The BASECASE model has no insulation in its walls and roofs. Insulation could be able to prevent heat gains. In this part for simulation, different thicknesses of polystyrene for walls and polyurethane (tight diffusion) for pitched roofs were applied. Table 5 shows various details that were examined for bungalow house.

Table 5: Wall and roof insulation

\begin{tabular}{|c|c|c|}
\hline Abbreviation & \multicolumn{2}{|c|}{ U-value $\left(\mathrm{W} / \mathrm{m}^{2} / \mathrm{K}\right)$ Specification from outside to inside } \\
\hline Wall 1(BASECASE model) & 2.319 & $\begin{array}{l}\text { cement sand render } 1.3 \mathrm{~cm} \text {, concrete blocks (medium) } \\
11 \mathrm{~cm} \text {, gypsum plaster } 1.3 \mathrm{~cm}\end{array}$ \\
\hline Wall 2 & 0.766 & $\begin{array}{l}\text { cement sand render } 1.3 \mathrm{~cm} \text {, concrete blocks } 11 \mathrm{~cm} \text {, } \\
\text { polystyrene } 3.5 \mathrm{~cm} \text {, gypsum plaster } 1.3 \mathrm{~cm}\end{array}$ \\
\hline Wall 3 & 0.595 & $\begin{array}{l}\text { cement sand render } 1.3 \mathrm{~cm} \text {, concrete blocks } 11 \mathrm{~cm} \text {, } \\
\text { polystyrene } 5 \mathrm{~cm} \text {, gypsum plaster } 1.3 \mathrm{~cm}\end{array}$ \\
\hline Wall 4 & 0.434 & $\begin{array}{l}\text { cement sand render } 1.3 \mathrm{~cm} \text {, concrete blocks } 11 \mathrm{~cm} \text {, } \\
\text { polystyrene } 7.5 \mathrm{~cm} \text {, gypsum plaster } 1.3 \mathrm{~cm}\end{array}$ \\
\hline Wall 5 & 0.341 & $\begin{array}{l}\text { cement sand render } 1.3 \mathrm{~cm} \text {, concrete blocks } \\
11 \mathrm{~cm} \text {, polystyrene } 10 \mathrm{~cm} \text {, gypsum plaster } 1.3 \mathrm{~cm}\end{array}$ \\
\hline Roof 1(BASECASE model) & 0.543 & concrete tile $2 \mathrm{~cm}$, air gap $10 \mathrm{~cm}$, wooden batons $20 \mathrm{~cm}$ \\
\hline Roof 2 & 0.265 & $\begin{array}{l}\text { concrete tile } 2 \mathrm{~cm} \text {, air gap } 10 \mathrm{~cm} \text {, aluminum foil, } \\
\text { polyurethane } 5 \mathrm{~cm} \text {, wooden batons } 20 \mathrm{~cm}\end{array}$ \\
\hline Roof 3 & 0.211 & $\begin{array}{l}\text { concrete tile } 2 \mathrm{~cm} \text {, air gap } 10 \mathrm{~cm} \text {, aluminum foil, } \\
\text { polyurethane } 7.5 \mathrm{~cm} \text {, wooden batons } 20 \mathrm{~cm}\end{array}$ \\
\hline Roof 4 & 0.176 & $\begin{array}{l}\text { concrete tile } 2 \mathrm{~cm} \text {, air gap } 10 \mathrm{~cm} \text {, aluminum foil, } \\
\text { polyurethane } 10 \mathrm{~cm} \text {, wooden batons } 20 \mathrm{~cm}\end{array}$ \\
\hline
\end{tabular}


Simulation results illustrate that master bedroom with $3.5 \mathrm{~cm}$ polystyrene insulation in inner side of external walls (Wall 2) has $21.4 \%$ energy saving in chiller electricity consumption (Figure 6). External walls with insulation layer thickness of $5 \mathrm{~cm}, 7.5 \mathrm{~cm}$ and $10 \mathrm{~cm}$ have $24.6 \%, 27.8 \%$ and $29.8 \%$ chiller electricity saving in comparison with BASCASE model, respectively. About roof insulation, various thicknesses of polyurethane layers with attached aluminum foil were simulated. The results show that $5 \mathrm{~cm}, 7.5 \mathrm{~cm}$ and $10 \mathrm{~cm}$ polyurethane layers have $3.6 \%, 4.4 \%$ and $26.1 \%$ cooling electricity saving, respectively. So, $10 \mathrm{~cm}$ polyurethane insulation layer could have suitable response for roof insulation of building envelope (Roof 4). Integration of roof and wall insulation has various declines in chiller electricity. Roof 2 with wall 2 lessen $26 \%$ of chiller electricity of BASECASE model while the most energy saving is for roof 4 with wall 5 with $36.4 \%$.

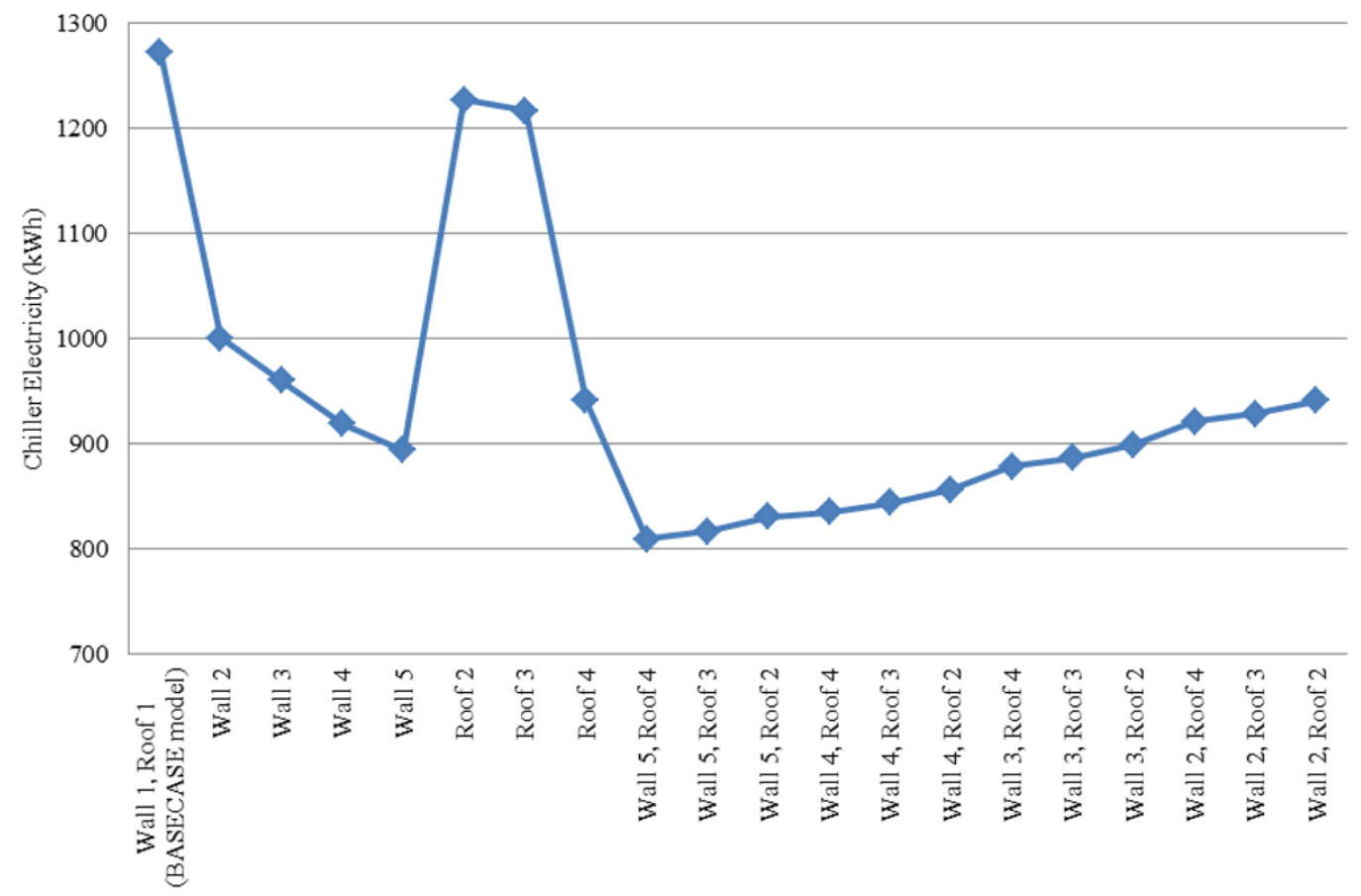

Figure 6: Chiller electricity (kWh) and insulated walls and roofs

\subsubsection{Orientation}

The BASECASE model has been located in east-west orientation. Master bedroom has two external walls that have oriented to west and north. In this stage impact of orientation is considered for energy consumption of master bedroom with $45^{\circ}$ counter clockwise rotation. In addition, it should be mentioned that west and north wall of master bedroom have $43 \%$ and $10.6 \%$ window to wall ratio, respectively and there is a balcony attached to west wall. Table 6 indicates tested master bedrooms for simulation with "DB" and their cooling electricity. 
Table 6: Tested different orientation for master bedroom and cooling electricity

\begin{tabular}{|c|c|c|}
\hline Abbreviation & Orientation of two external walls & Chiller electricity $(\mathrm{kWh})$ \\
\hline Master bedroom 1 & west - north (BASECASE model) & 1273.3 \\
\hline Master bedroom 2 & south west - north west $\left(45^{\circ}\right.$ rotation) & 1343.12 \\
\hline Master bedroom 3 & south - west (90 rotation) & 1425.8 \\
\hline Master bedroom 4 & south east - south west $\left(135^{\circ}\right.$ rotation $)$ & 1360.57 \\
\hline Master bedroom 5 & east - south $\left(180^{\circ}\right.$ rotation $)$ & 1269.24 \\
\hline Master bedroom 6 & north east - south east $\left(225^{\circ}\right.$ rotation $)$ & 1333.21 \\
\hline Master bedroom7 & north - east (270 rotation) & 1415.77 \\
\hline Master bedroom8 & north west - north east $\left(315^{\circ}\right.$ rotation) & 1362.6 \\
\hline
\end{tabular}

Figure 7 shows the result of house rotation on chiller electricity. It could be understood that suitable orientations for bungalow house is east-west. Master bedrooms with external walls towards east-south ( $180^{\circ}$ rotation) or west-north (BASECASE model) have suitable energy efficiency. Fluctuation of chiller electricity consumption between best and worst orientation is $12.3 \%$. BASECASE model with $90^{\circ} \mathrm{C}$ rotation will need $12 \%$ more cooling electricity demand. While with $180^{\circ} \mathrm{C}$ rotation will have $0.3 \%$ less cooling electricity consumption. In addition, $45^{\circ} \mathrm{C}$ rotation toward east $\left(225^{\circ} \mathrm{C}, 45^{\circ} \mathrm{C}\right)$ and west $\left(135^{\circ} \mathrm{C}, 315^{\circ} \mathrm{C}\right)$ have next places with respect to energy consumption, respectively.

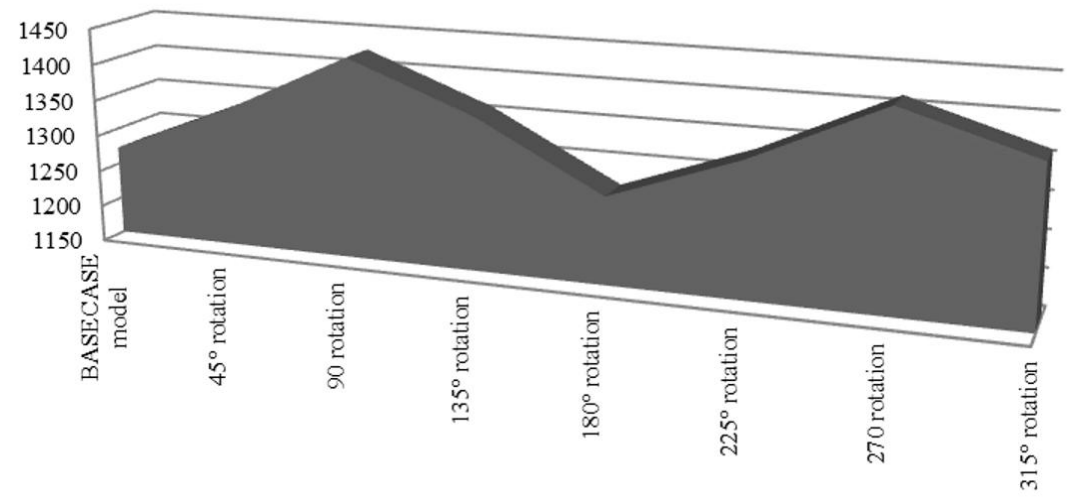

Figure 7: Chiller electricity (kWh) and different house orientations

\subsubsection{Window to Wall Area Ratio}

Area ratio of window to wall is an important criterion for architecture design. Also, it has significant influence on building comfort condition such as thermal, acoustic, visual comfort and energy consumption. In this section, different ratios of window to wall area of west and north walls of master bedroom are examined. Selected WWRs are considered between 10-40\%. For appropriate results of influence of WWR factor, balcony of BASECASE model was omitted. Table 7 shows simulated master bedrooms and their annual chiller electricity 
demands. It could be seen that master bedroom with west $40 \%$, north $40 \%$ WWRs has $33.15 \%$ more chiller electricity consumption than master bedroom with west 10\%, north 10\% WWRs. Decreasing WWR for both exterior walls from $30 \%$ to $20 \%$ will cause $9 \%$ energy saving. These results highlight the importance of WWR in cooling energy consumption of master bedroom.

Table 7: Simulated window to wall area of master bedroom in different orientations

\begin{tabular}{|lll|}
\hline Abbreviation & Window to wall ratio & Chiller electricity (kWh) \\
Master bedroom 1 & west 10\% north 10\%, without balcony & 1647.27 \\
Master bedroom 2 & west 10\% north 20\%, without balcony & 1735.56 \\
Master bedroom 3 & west 10\% north 30\%, without balcony & 1820.45 \\
Master bedroom 4 & west 10\% north 40\%, without balcony & 1905.12 \\
Master bedroom 5 & west 20\% north 10\%, without balcony & 1749.78 \\
Master bedroom 6 & west 20\% north 20\%, without balcony & 1836.7 \\
Master bedroom 7 & west 20\% north 30\%, without balcony & 1920.3 \\
Master bedroom 8 & west 20\% north 40\%, without balcony & 2003.19 \\
Master bedroom 9 & west30\% north 10\%, without balcony & 1851.34 \\
Master bedroom 10 & west30\% north 20\%, without balcony & 1936.69 \\
Master bedroom 11 & west30\% north 30\%, without balcony & 2017.89 \\
Master bedroom 12 & west30\% north 40\%, without balcony & 2098.04 \\
Master bedroom 13 & west40\% north 10\%, without balcony & 1951.28 \\
Master bedroom 14 & west40\% north 20\%, without balcony & 2037.62 \\
Master bedroom 15 & west40\% north 30\%, without balcony & 2116.6 \\
Master bedroom 16 & west40\% north 40\%, without balcony & 2193.43
\end{tabular}

For examining the effect of WWR on west and north walls, linear regression model of each wall separately has determined (Figures 8-11). $\mathrm{R}^{2}$ values of regression are above 0.99 that indicates appropriateness of linear relation of WWR and chiller electricity. These linear models included WWR of west and north wall (one wall with permanent WWR and other wall with varied amount of WWR) and chiller electricity. These figures helped to understand the effect of change of WWR on annual chiller electricity. Figure 8 displays that higher WWR in north wall has less effect on energy consumption than same WWR in west wall. For example, chiller electricity of master bedroom with $10 \%$ WWR in west wall and $30 \%$ WWR in north wall $(1820.45 \mathrm{kWh})$ is less than same space with $10 \%$ WWR in north wall and 30\% WWR in west wall (1851.34 kWh). The difference is $1.6 \%$. This condition could also be realized in Figures 9-11. This means that master bedroom with higher WWR in north wall has more energy saving than master bedroom with higher WWR in west wall. However, this difference is not so intensive. Therefore, energy saving condition would be changed easily in integration with other passive strategies like balcony, shading and etc. Also, it could be seen that slope of linear formulas for varied west wall is more than varied north wall. It indicates WWR change in west wall has more effect than north wall of master bedroom of BASECASE model. 


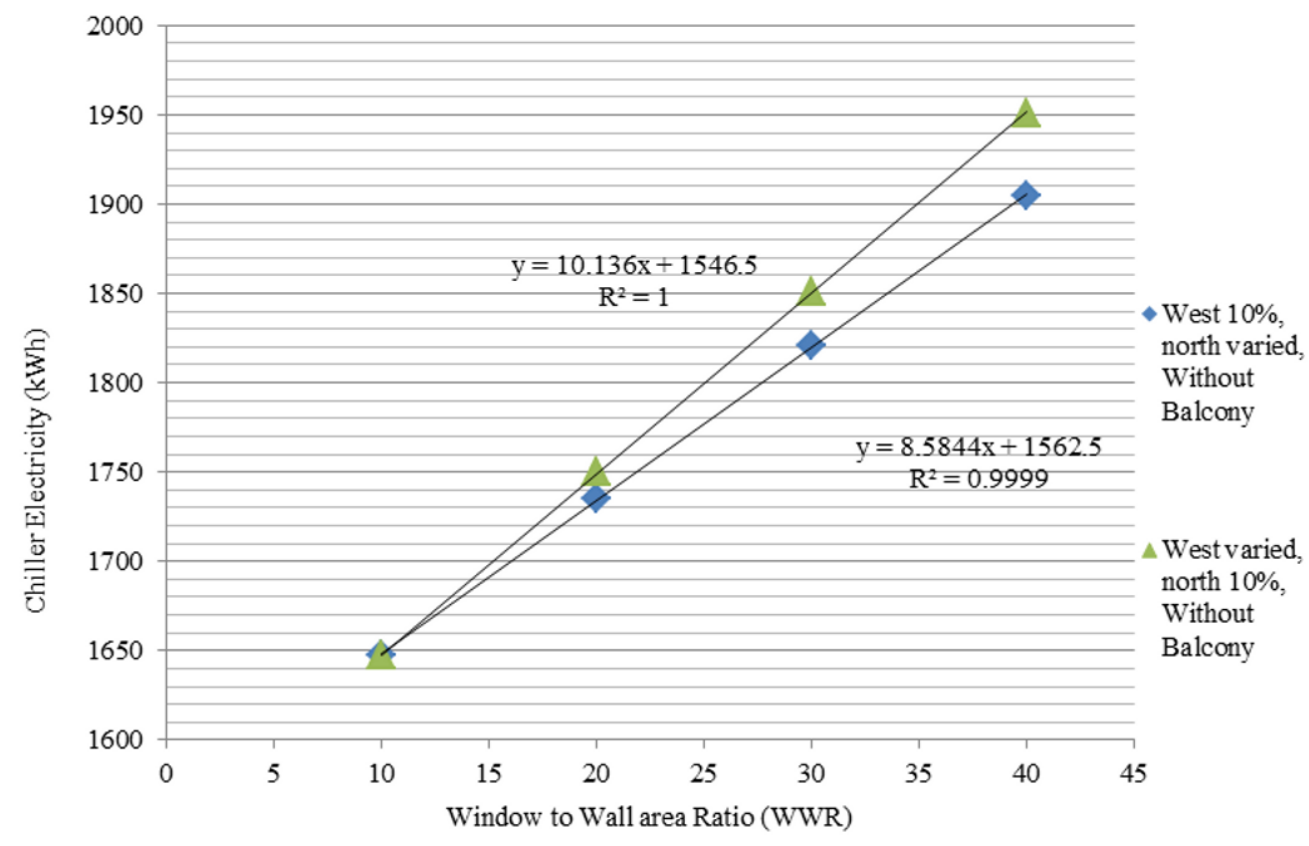

Figure 8: Chiller Electricity and WWR: one wall with 10\% WWR, other wall with varied WWR

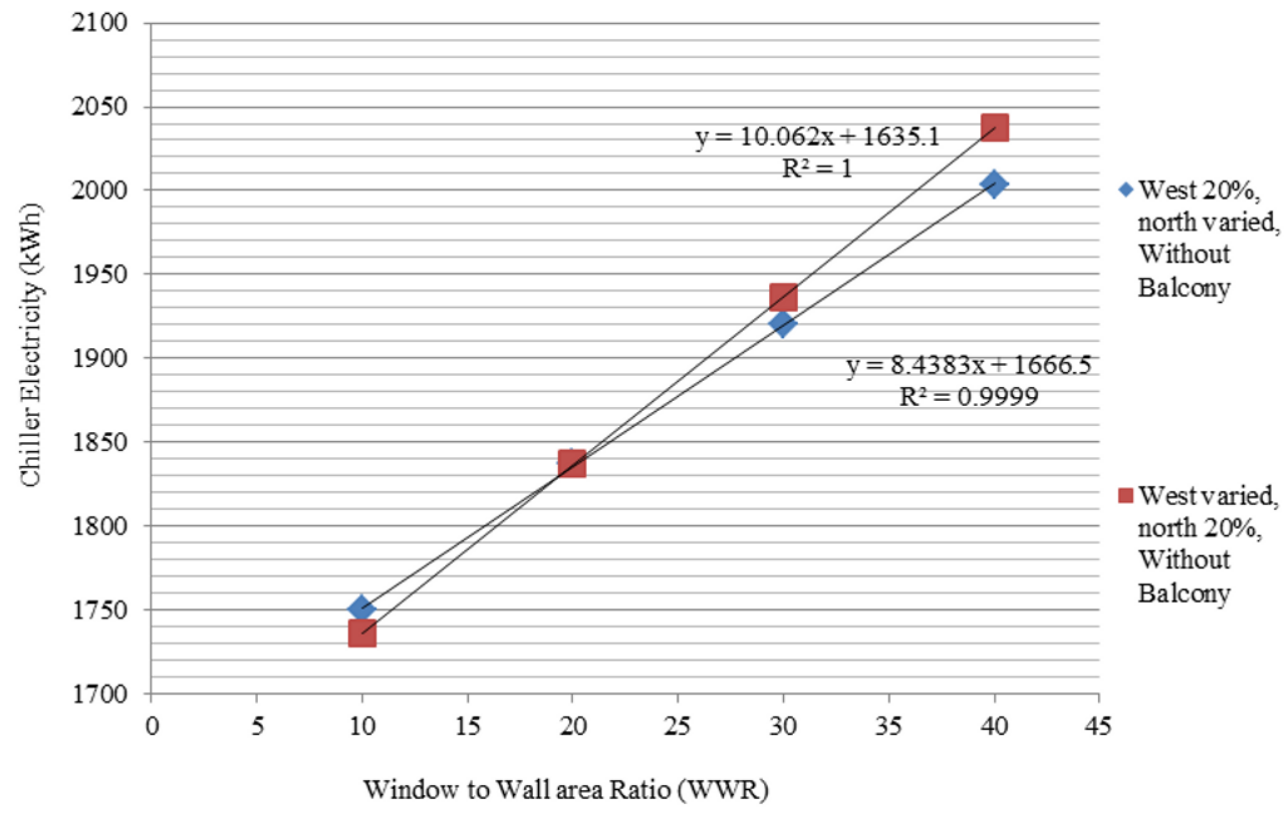

Figure 9: Chiller Electricity and WWR: one wall with $20 \%$ WWR, other wall with varied WWR 


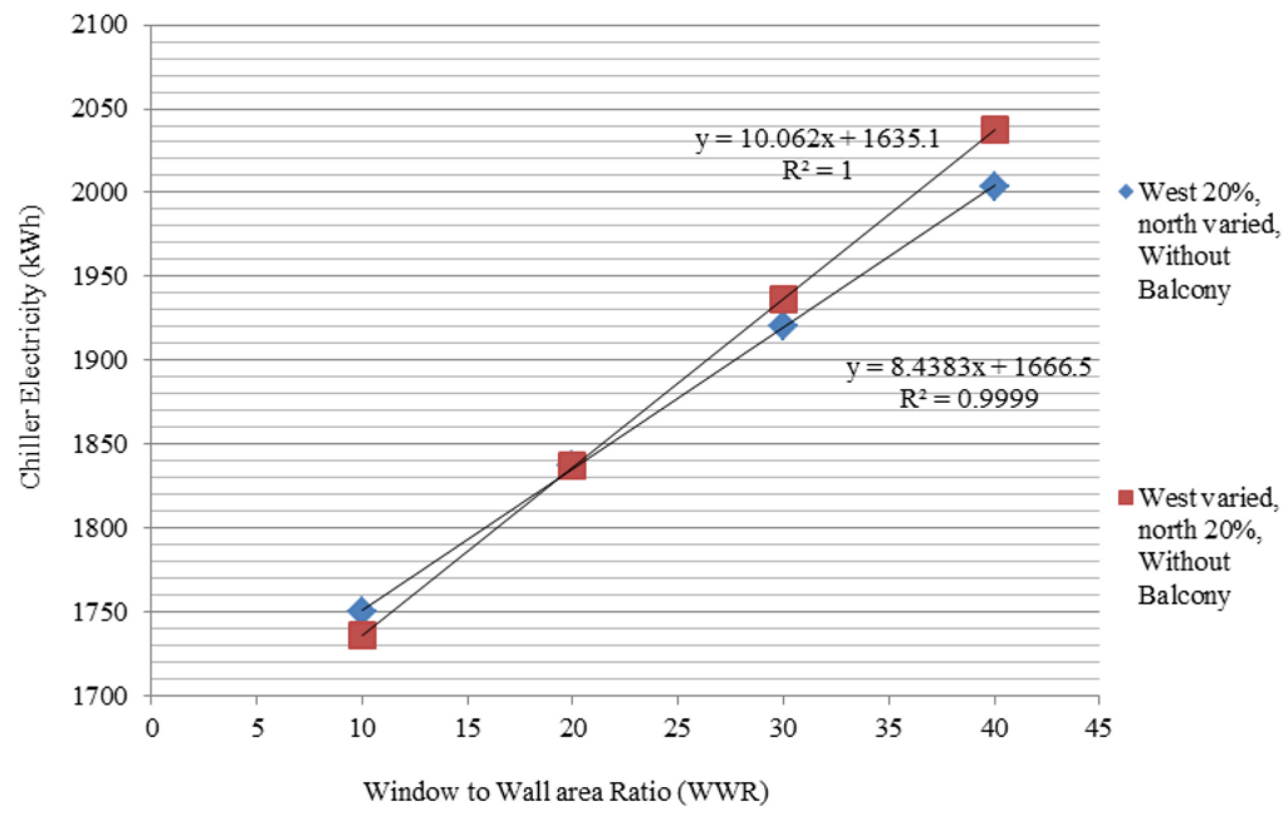

Figure 10: Chiller Electricity and WWR: one wall with 30\% WWR, other wall with varied WWR

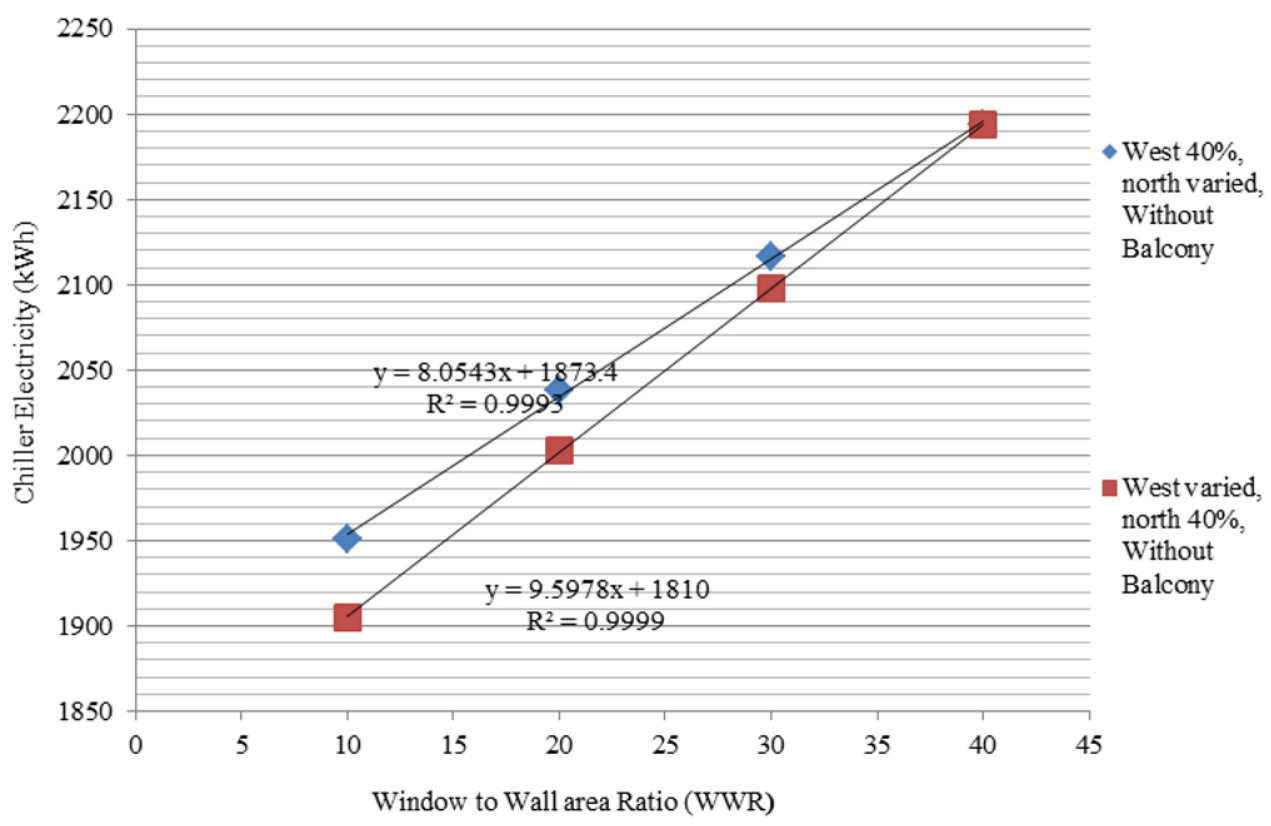

Figure 11: Chiller Electricity and WWR: one wall with $40 \%$ WWR, other wall with varied WWR

\subsubsection{Balcony and its Location}

Balcony as an architectural element could help reduce energy consumption. So it prevents solar heat gain by external walls and reduces solar heat entrance via windows. In this section, four different possibilities are 
considered. BASECASE model with balcony in westward, other model with balcony in northward, without balcony model and another model with attached balcony to both external walls are simulated. According to simulation results, transferring balcony from west to north will increase chiller electricity around 19\%. In other words, balcony attached to west wall has more effect than north wall balcony. Adding balcony to north wall could reduce $10 \%$ of chiller electricity of BASECASE model. Bungalow house without balcony will consume $31 \%$ more cooling energy than BASECASE model (Figure 12). So, existence of balcony in front of both external walls will help energy efficiency of building.

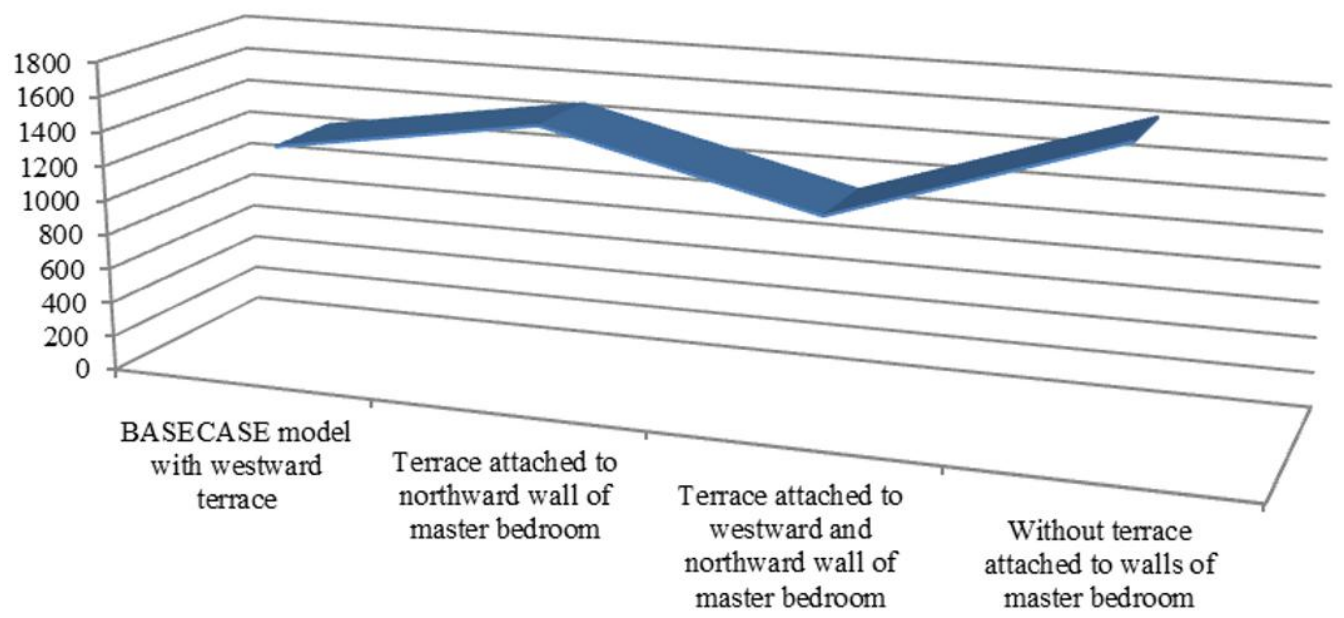

Figure 12: Chiller Electricity and Balcony and its Location

\subsection{Cooling Set Point Temperature}

House residents have good flexibility to achieve adaptive thermal comfort. They could change clothes, drink, take a bath and do other adaptive works. Peeters et al. (2009) have determined that houses could have three different thermal comfort zones. These are bedrooms, bathrooms and other rooms. These zones would have three different neutral temperatures. Master bedroom needs to have specific cooling set point temperature. According to Peeters et al. (2009) upper limit of neutral temperature of master bedroom for climates with reference external temperature more than $21.8^{\circ} \mathrm{C}$ is $26^{\circ} \mathrm{C}$ (Peeters, Dear, Hensen, \& D'Haeseleer, 2009). These results were derived from European context.

On the other hand, Fanger \& Toftum (2002) proposed for non-air-conditioned buildings, the expectancy factor which is assumed depends on the duration of the warm weather over the year and whether such building can be compared with many others in the region that are air conditioned. If the weather is warm all year or most of the year and there are no or few air-conditioned buildings, the expectancy factor maybe 0.5 , while it may be 0.7 if there are many other buildings with air conditioning. A low expectation may change the upper temperature limit by $2^{\circ} \mathrm{C}$ (Fanger \& Toftum, 2002). Neutral temperature also affected with psychological and physiological adaptations such as people‘s experiences, habituations and acclimatization. 
From mentioned subjects, it would be assumed that habituations of people and weather of Malaysia could allow some high neutral temperatures but it is essential to have more experimental studies for achieving upper limit of neutral temperature. So, in this part, 3 different cooling set point temperatures are considered. These temperatures are $26^{\circ} \mathrm{C}, 27^{\circ} \mathrm{C}$ and $28^{\circ} \mathrm{C}$. Figure 13 shows chiller electricity for different cooling set points. With assuming $28^{\circ} \mathrm{C}$ as set point temperature of BASECASE model, decreasing it to $27^{\circ} \mathrm{Cand} 26^{\circ} \mathrm{C}$ will cause $70 \%$ and $148 \%$ increase of chiller electricity, respectively. These significant amounts remind us about importance of definition of cooling set point temperature with respect to life style and local habituations to decrease energy consumption.

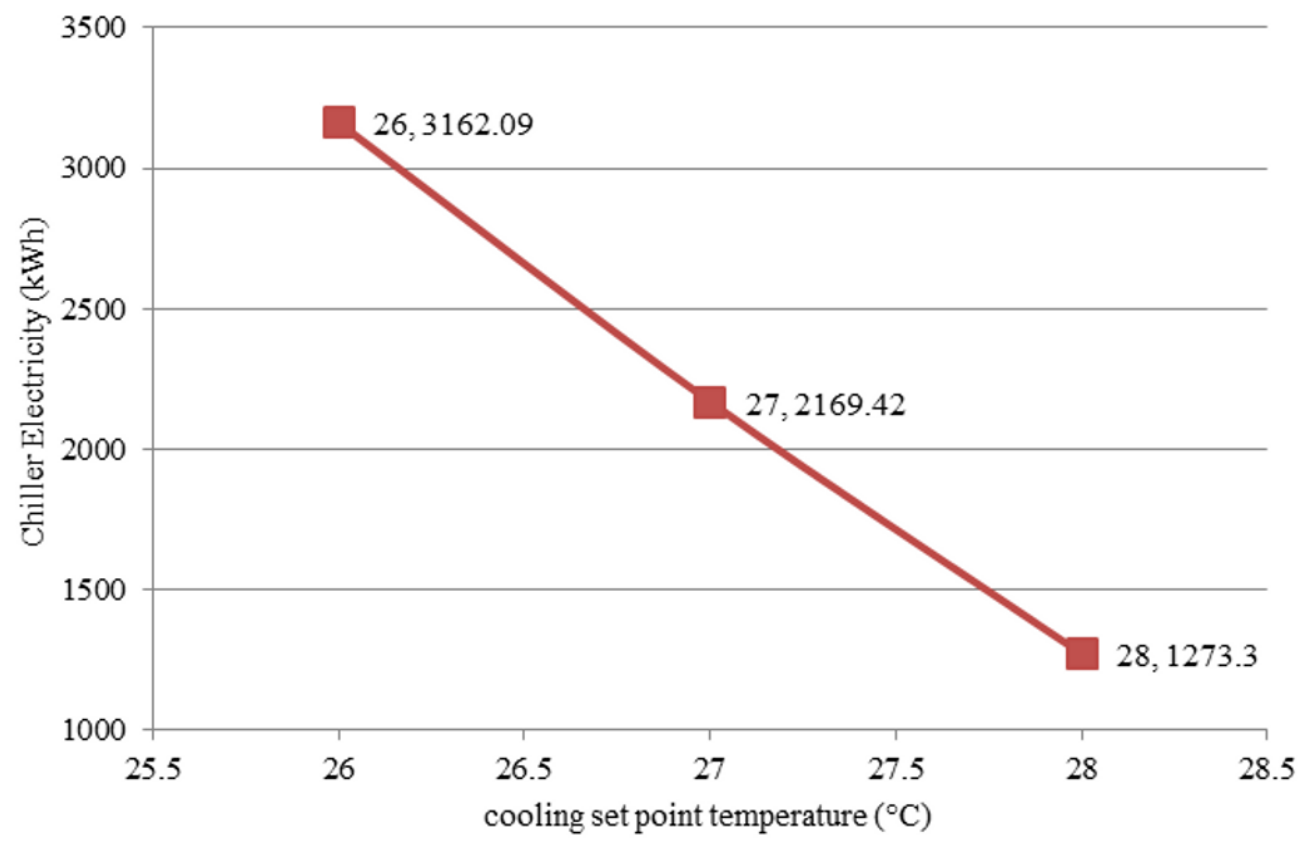

Figure 13: Chiller Electricity and different cooling set points

\subsection{Integrative Strategies}

Results show that an appropriate window has72.6\% energy saving for BASECASE model. With suitable insulation of walls and roofs $36.4 \%$ of cooling energy could be saved. Best orientation has $0.3 \%$ energy saving for BASECASE but $12.3 \%$ is difference between energy consumption of best and worst orientations. There is $33.15 \%$ saved energy if WWR in external walls change from $40 \%$ to $10 \%$. Higher WWR for north wall is more energy efficient than west wall. Balcony attached to both side of external walls will reduce $31 \%$ cooling energy consumption of master bedroom without balcony.

In this stage, a bungalow house is proposed in accordance with strategies examined in previous sections. These properties have presented in Table 8 and could be compared with BASECASE model. 


\section{Table 8: Comparison of proposed house and BASECASE model}

\begin{tabular}{|c|c|c|}
\hline Strategies & BASECASE model & d house \\
\hline Window type & $\begin{array}{l}\text { single glazing clear, glass } \\
6 \mathrm{~mm} \text {, aluminum frame }\end{array}$ & $\begin{array}{l}\text { Double glazing reflective with shading, outer pane: } \\
\text { reflective, metallic (stainless steel) painted, low } \\
\text { emissivity, } 6 \mathrm{~mm} \text {, inner pane: clear } 6 \mathrm{~mm} \text {, window gap } \\
\text { type: argon filled } 13 \mathrm{~mm} \text {, aluminum frame, } 1 \mathrm{~m} \\
\text { louver, } 1 \mathrm{~m} \text { overhang and side fins }\end{array}$ \\
\hline Wall & $\begin{array}{l}\text { cement sand render } 1.3 \mathrm{~cm}, \\
\text { concrete blocks (medium) } \\
11 \mathrm{~cm} \text {, gypsum plaster } 1.3 \mathrm{~cm}\end{array}$ & $\begin{array}{l}\text { cement sand render } 1.3 \mathrm{~cm} \text {, concrete blocks } 11 \mathrm{~cm} \\
\text {, polystyrene } 10 \mathrm{~cm} \text {, gypsum plaster } 1.3 \mathrm{~cm}\end{array}$ \\
\hline Roof & $\begin{array}{l}\text { concrete tile } 2 \mathrm{~cm} \text {, air gap } \\
10 \mathrm{~cm} \text {, wooden batons } 20 \mathrm{~cm}\end{array}$ & $\begin{array}{l}\text { concrete tile } 2 \mathrm{~cm} \text {, air gap } 10 \mathrm{~cm} \text {, aluminum foil, } \\
\text { polyurethane } 10 \mathrm{~cm} \text {, wooden batons } 20 \mathrm{~cm}\end{array}$ \\
\hline Orientation & $\begin{array}{l}\text { two exterior walls toward } \\
\text { west and north }\end{array}$ & two exterior walls toward west and north \\
\hline WWR & west wall $42 \%$, north wall $10.6 \%$ & west wall $10 \%$, north wall $40 \%$ \\
\hline Balcony & attached to west wall & attached to west and north wall \\
\hline
\end{tabular}

In suggested house, orientation has not been changed because its influence is only $0.3 \%$ compared with BASECASE model. Also changing of orientation will need to express of WWR impact on other oriented walls which are not explored in this study. Simulation results show that there is approximately no need for chiller cooling of the master bedroom when cooling set point is $28^{\circ} \mathrm{C}$ because inside temperature comes lower than this temperature. Annual chiller electricity of master bedroom was only $0.56 \mathrm{kWh}$. While decreasing cooling set point to $27^{\circ} \mathrm{C}$ and $26^{\circ} \mathrm{C}$ will cause demand for chiller cooling. Simulation results indicate that chiller electricity consumptions of proposed house for $27^{\circ} \mathrm{C}$ and $26^{\circ} \mathrm{C}$ cooling set points are $53.8 \mathrm{kWh}$ and $408.1 \mathrm{kWh}$. While chiller electricity for BASECASE model with $27^{\circ} \mathrm{C}$ and $26^{\circ} \mathrm{C}$ cooling set points are $2169.4 \mathrm{kWh}$ and $3162.1 \mathrm{kWh}$, respectively. In other words, master bedroom of proposed house saves $97.5 \%$ and $87 \%$ chiller electricity for $27^{\circ} \mathrm{C}$ and $26^{\circ} \mathrm{C}$ cooling set points in comparison with BASECASE model.

\section{Conclusions}

Simulation results by "DesignBuilder" showed that some considerations in house design could reduce and even omit cooling demands. Five simple strategies were explored to reduce cooling energy consumption in master bedroom of a bungalow house. Applying an appropriate window, suitable insulation of walls and roofs, proper orientation, moderate ratio of window to wall area and relevant balcony will cause significant energy savings. Double glazed windows with stainless steel coated, argon filled, low emissivity and reflective glass that it has $1 \mathrm{~m}$ louver, $1 \mathrm{~m}$ overhang and side fins save $72.6 \%$ chiller electricity for master bedroom. Also, walls with $10 \mathrm{~cm}$ 
polystyrene save $29.8 \%$ cooling electricity and a pitched roof with $10 \mathrm{~cm}$ polyurethane (diffusion tight) saves $26.1 \%$ chiller electricity. An east - west oriented bungalow house ( $180^{\circ}$ rotation) saves $12.3 \%$ more chiller electricity in comparison with north - south oriented bungalow house (90 rotation). Higher WWR for north wall is more relevant than west wall. But difference of energy saving is not so intensive. For example, a master bedroom with $40 \%$ WWR in north wall and $10 \%$ in west wall saves $2.4 \%$ more energy than that room with $40 \%$ WWR in west wall and $10 \%$ WWR in north wall. Existence of balconies with $1.6 \mathrm{~m}$ depth attached to both external walls decline $10 \%$ chiller electricity of BASECASE model. In addition comparison of proposed house and BASECASE model shows that appropriate window, walls insulation, roof insulation, balcony, WWR and orientation have highest to lowest influence on energy saving, respectively. Integration of these strategies pointed out that master bedroom of proposed house has approximately no need for chiller electricity when cooling set point is $28^{\circ} \mathrm{C}$. Also, this space with $27^{\circ} \mathrm{C}$ and $26^{\circ} \mathrm{C}$ cooling set points has $97.5 \%$ and $87 \%$ more saving of cooling energy rather than its counterparts in BASECASE model. This matter demonstrates energy efficiency of passive strategies for master bedroom of bungalow house.

In future studies could be concentrated on different components of bungalow house to determine impact of each element on energy efficiency of building envelope. For example, walls, roofs and floors with different details could influence on energy performance of building. This attention would help to improve architecture designs and present guidelines for design of low energy cooled buildings.

\section{References}

Ahmad, S. S. (2008). Kuala Lumpur: a hot humid climate. In R. Hyde (Ed.), Bioclimatic Housing Innovative Designs for Warm Climates (pp. 260-293). London: Earthscan.

Cheung, C. K., Fuller, R. J., \& Luther, M. B. (2005). Energy-efficient envelope design for high-rise apartments. Energy and Buildings, 37(1), 37-48. doi: DOI: 10.1016/j.enbuild.2004.05.002

Fanger, P. O., \& Toftum, J. (2002). Extension of the PMV model to non-air-conditioned buildings in warm climates. Energy and Buildings, 34(6), 533-536. doi: Doi: 10.1016/s0378-7788(02)00003-8

Garde, F., Adelard, L., Boyer, H., \& Rat, C. (2004). Implementation and experimental survey of passive design specifications used in new low-cost housing under tropical climates. Energy and Buildings, 36(4), 353-366. doi: DOI: 10.1016/j.enbuild.2004.01.045

http://apps1.eere.energy.gov/buildings/energyplus/. Energy Plus: U.S. Department of Energy.

Kubota, T., Chyee, D. T. H., \& Ahmad, S. (2009). The effects of night ventilation technique on indoor thermal environment for residential buildings in hot-humid climate of Malaysia. Energy and Buildings, 41(8), 829839. doi: DOI: $10.1016 /$ j.enbuild.2009.03.008

Ligget, R., \& Milne, M. (2008). Climate consultant 4. UCLA, Los Angeles: Energy Design Tool Group.

Peeters, L., Dear, R. d., Hensen, J., \& D'Haeseleer, W. (2009). Thermal comfort in residential buildings: Comfort values and scales for building energy simulation. Applied Energy, 86(5), 772-780. doi: DOI: 10.1016/j.apenergy.2008.07.011 
Perez, Y. V., \& Capeluto, I. G. (2009). Climatic considerations in school building design in the hot-humid climate for reducing energy consumption. Applied Energy, 86(3), 340-348. doi: DOI: 10.1016/j.apenergy.2008.05.007

Radhi, H., Eltrapolsi, A., \& Sharples, S. (2009). Will energy regulations in the Gulf States make buildings more comfortable - A scoping study of residential buildings. Applied Energy, 86(12), 2531-2539. doi: DOI: 10.1016/j.apenergy.2009.04.003

Rahman, M. M., Rasul, M. G., \& Khan, M. M. K. (2010). Energy conservation measures in an institutional building in sub-tropical climate in Australia. Applied Energy, 87(10), 2994-3004. doi: DOI: 10.1016/j.apenergy.2010.04.005

Saidur, R. (2009). Energy consumption, energy savings, and emission analysis in Malaysian office buildings. Energy Policy, 37(10), 4104-4113. doi: DOI: 10.1016/j.enpol.2009.04.052

Saidur, R., Masjuki, H. H., \& Jamaluddin, M. Y. (2007). An application of energy and exergy analysis in residential sector of Malaysia. Energy Policy, 35(2), 1050-1063. doi: DOI: 10.1016/j.enpol.2006.02.006

Swan, L. G., \& Ugursal, V. I. (2009). Modeling of end-use energy consumption in the residential sector: A review of modeling techniques. Renewable and Sustainable Energy Reviews, 13(8), 1819-1835. doi: DOI: 10.1016/j.rser.2008.09.033

Szokolay, S. V. (2008). Introduction to Architectural Science: the basis of sustainable design (Second Edition ed.). Oxford: Architectural Press.

Tindale, A. (2002) Retrieved 1/11/2010, from www.designbuilder.co.uk

Yu, J., Yang, C., \& Tian, L. (2008). Low-energy envelope design of residential building in hot summer and cold winter zone in China. Energy and Buildings, 40(8), 1536-1546. doi: DOI: 10.1016/j.enbuild.2008.02.020

Ahmad, S. S. (2008). Kuala Lumpur: a hot humid climate. In R. Hyde (Ed.), Bioclimatic Housing Innovative Designs for Warm Climates (pp. 260-293). London: Earthscan.

Cheung, C. K., Fuller, R. J., \& Luther, M. B. (2005). Energy-efficient envelope design for high-rise apartments. Energy and Buildings, 37(1), 37-48. doi: DOI: 10.1016/j.enbuild.2004.05.002

Garde, F., Adelard, L., Boyer, H., \& Rat, C. (2004). Implementation and experimental survey of passive design specifications used in new low-cost housing under tropical climates. Energy and Buildings, 36(4), 353-366. doi: DOI: 10.1016/j.enbuild.2004.01.045

http://apps1.eere.energy.gov/buildings/energyplus/. Energy Plus: U.S. Department of Energy.

http://apps1.eere.energy.gov/buildings/energyplus/cfm/weather_data3.cfm/region5_southwest_pacific_wmo_region 5/country=MYS/cname=Malaysia. Weather file of Kuala Lumpur, Applied for Energy Plus Program Retrieved 10 July, 2010

Kubota, T., Chyee, D. T. H., \& Ahmad, S. (2009). The effects of night ventilation technique on indoor thermal environment for residential buildings in hot-humid climate of Malaysia. Energy and Buildings, 41(8), 829839. doi: DOI: $10.1016 /$ j.enbuild.2009.03.008

Ligget, R., \& Milne, M. (2008). Climate consultant 4. UCLA, Los Angeles: Energy Design Tool Group. 
Ole Fanger, P., \& Toftum, J. (2002). Extension of the PMV model to non-air-conditioned buildings in warm climates. Energy and Buildings, 34(6), 533-536. doi: Doi: 10.1016/s0378-7788(02)00003-8

Peeters, L., Dear, R. d., Hensen, J., \& D'Haeseleer, W. (2009). Thermal comfort in residential buildings: Comfort values and scales for building energy simulation. Applied Energy, 86(5), 772-780. doi: DOI: 10.1016/j.apenergy.2008.07.011

Perez, Y. V., \& Capeluto, I. G. (2009). Climatic considerations in school building design in the hot-humid climate for reducing energy consumption. Applied Energy, 86(3), 340-348. doi: DOI: 10.1016/j.apenergy.2008.05.007

Radhi, H., Eltrapolsi, A., \& Sharples, S. (2009). Will energy regulations in the Gulf States make buildings more comfortable - A scoping study of residential buildings. Applied Energy, 86(12), 2531-2539. doi: DOI: 10.1016/j.apenergy.2009.04.003

Rahman, M. M., Rasul, M. G., \& Khan, M. M. K. (2010). Energy conservation measures in an institutional building in sub-tropical climate in Australia. Applied Energy, 87(10), 2994-3004. doi: DOI: 10.1016/j.apenergy.2010.04.005

Saidur, R. (2009). Energy consumption, energy savings, and emission analysis in Malaysian office buildings. Energy Policy, 37(10), 4104-4113. doi: DOI: 10.1016/j.enpol.2009.04.052

Saidur, R., Masjuki, H. H., \& Jamaluddin, M. Y. (2007). An application of energy and exergy analysis in residential sector of Malaysia. Energy Policy, 35(2), 1050-1063. doi: DOI: 10.1016/j.enpol.2006.02.006

Swan, L. G., \& Ugursal, V. I. (2009). Modeling of end-use energy consumption in the residential sector: A review of modeling techniques. Renewable and Sustainable Energy Reviews, 13(8), 1819-1835. doi: DOI: 10.1016/j.rser.2008.09.033

Szokolay, S. V. (2008). Introduction to Architectural Science: the basis of sustainable design (Second Edition ed.). Oxford: Architectural Press.

Tindale, A. (2002), from www.designbuilder.co.uk

Yu, J., Yang, C., \& Tian, L. (2008). Low-energy envelope design of residential building in hot summer and cold winter zone in China. Energy and Buildings, 40(8), 1536-1546. doi: DOI: 10.1016/j.enbuild.2008.02.020 